\title{
An Overview of Anti-Competitive Conditions in America
}

\author{
Ashkan Naghdi $^{1} \&$ Ali Gharibeh $^{1}$ \\ ${ }^{1}$ East Azarbaijan Research and Science, Iran \\ Correspondence: Ashkan Naghdi, East Azarbaijan Research and Science, Iran. E-mail: \\ ashkannaghdi@yahoo.com
}

Received: December 23, 2015 Accepted: January 15, 2016 Online Published: March 31, 2016

doi:10.5539/jpl.v9n2p49

URL: http://dx.doi.org/10.5539/jpl.v9n2p49

\begin{abstract}
Influential branch of public law, competition law and encompasses a series of positive and negative regulation of the market that are aimed at controlling entity into existence. A great scholar of Rights and the science of economics politicians in explored this is a complex issue yet have important principles and it works its growth strategies and behaviors and avoid imposing hundreds competitive review.it can be another success in various fields such as political, military, and...and competitive.... Its goal is to compete at a high level stable investments.
\end{abstract}

Keywords: competition, monopoly, dumping, unfair behavior

\section{Introduction}

knows. notion of competition in America and Canada in countries that are major trading either directly through the manufacturing and production of the goods will be broadcasting stems (Hosted, Feb 2011, p7). 's rights in America anti-competitive behavior in America of a century that has arisen and is now global (Hosted, 2010, p11). these provisions of the Act are due to modern trade. in America at the beginning of the anti-competitive provisions in relation to the multiple political goals in 5

\section{Literature Review}

In this section respectively, of the theoretical research undertaken research methodology, the research objectives and the research findings will be presented.

\subsection{Theoretical Research}

was clearly evident in the competition and objectivity, which was the legal scholars on intellectual being sick wearing their competition..., p38) anti-competitive regulations unusually some legal relation or (claims) to be applied in cases when it is possible to continually investigated the matter have to continue. in the in the it is feared that the epidemic is rampant, resulting in disintegration of the competitive market framework. Firstly, the impact of competitive behavior of the parties will be like grinding. parties as the effects and results of the agreement, that be obtained. though this example we see that if the grinding mill to happen for example during grinding happens, who is to blame? reasons and factors conviction and acquittal What is what happened. reasons concerning the classification of individual behavior, as the other audit or litigation resulting from cleaning and regular Fanon enjoy getting to be hard.

\subsection{Need to Do Research}

In view of nessecarity of doing of Anti - Competitive condition in America, However, The author thought it was significant to research about it.I hope it would be useful.

\subsection{Research Methodology}

This paper aims at the research point of view, the application of data collection, is described that aims to achieve a consensus of experts familiar with the subject of the article.

\subsection{Research Objectives}

1) explain and clarify the principles of competition law in America

2) evaluate the strengths and weaknesses of competing rights in America

\subsection{Findings}

A: history of anti- competition law: 
In relation to anti-competitive salary history in America can say that anti-competitive regulations in the United States of America (MagnaKanta), one of the founders of the major economic enterprise is founded. Maintain a competitive market integration anti-competitive regulations require knows. notion of competition in America and Canada in countries that are major trading either directly through the manufacturing and production of the goods will be broadcasting stems (Hosted, Feb 2011, p7). 's rights in America anti-competitive behavior in America of a century that has arisen and is now global (Hosted, 2010, p11). these provisions of the Act are due to modern trade. in America at the beginning of the anti-competitive provisions in relation to the multiple political goals in 5 has long since emerged as the economy goes well and Dyryngy old economics generally start with the second book (by John Smith of national wealth) is. (Gilles, 2009, p14) based on

B: anti- competition law purposes:

The expression of anti-competitive purposes strangely it is easy to check. Precise definition of the objectives of this Regulation controversial indicate that the regulation of anti- competitive depending on the Pgvnh be reviewed Hosted, June 2010, p 44) (In fact, order is important is how and from what perspective thishavingthis issue the issue is different which makes the need for further inquiry into the hive to let politics get out of the main argument of the author is beyond the scope.

At that time, the market will grow to compete with the state (small company product and easy entry into the market of the same sex)

Close view of concentrated economic power in the hands of private persons and the protection of democratic government, 3) the social and moral purpose to achieve a healthier economy regulatory and competitive industrial and commercial institutions and principles of the trend towards ethics stimuli institutions was the National (Dinn, 2010, p7)

Of government intervention : the influence of competition on the field when it is practical or impractical competition (due to some cause or causes it is not possible) or is prevented or prohibited by these (banned) on the latter by the government specific regulations or private parties is under contract.

C: anti-competitive legal rights in America:

In this regard, it is known that a valid law and will be discussed separately:

The Sherman Act, passed in 1890, the oldest anti- competition law, the Sherman Act. 's Law, passed in 1890, was a nuclear state since the United States of America.

Article 1 of the Act prohibits any agreement on trade restrictions.for specific goods or services to trade or the like.

Clayton Act, passed in 1914 lawmakers created a product that pressure the Clayton Act. Clayton Act forbids any conduct that restricts trade.to behave anti- competitively in the initial state itself (for potent yet actualized is not.) House of Representatives, the Federal Trade Commission in 1914 adopted. 's law is a consequence of one new, and the establishment of the new Commission for the implementation of the lawextensive Sherman Act is indeed due to the exigencies of time and understand the shortcomings and disadvantages of the provisions of this law was of particular importance to enjoy. (Shield, Dec 2009, p68).

D: The role and influence monopoly and competitive market pricing in America:

Monopoly : Monopoly is applicable only oriented itself is not illegal per se (Dinn, 2008, p80).,... Is that any way for the economy and more importantly for Buzzer of the right and wrong and detrimental to competition whether from the obtained. Economists science of economics a monopoly means gives ((that artificially increase prices limit output is declining innovation in economics and is particularly competitive market practice.)). despite the monopoly of a theory or belief is harmful to the economy but this does not mean)). objectionable and does not refused (Dinn, 2008, p83).

Personal issues can be fully Mtqyn. existing regulations do not ever try to market and reduced its discretion not to ask and not to ask while holding it in normal mode Darndrqyb successful the insisting that competition should not be a monopoly when the race is won although the anti- competitive provisions of the regulations are not always clear and consistent on this issue at least there is no doubt that today the major stock market alone, the illegalBoard of trade Limited use or employment policies Najvanmdanh to adopt the goal of reaching a complete state monopoly on the market it's destructive behavior and actions to achieve these goals by the economic by virtue of 2 Mamnou of the Sherman Act illegal. even if firms do not achieve their target and cause the target to remain silent opening act is illegal businesses that cater to courts ((probably dangerous)) that did not need any Vmtqdndthe nationwide chain Ratskhyr like to own a monopoly on the market that works to get (Rutherford, 
2008, p77). what is the need for courts to prove the intent to achieve monopoly enterprises has There are some specific evidence indicating that destroys the competition or monopoly is established. means going above to read the meaning in contract law means nothing but a means to seize by force or pressureessential ((intent)) has special meaning here is used to honest competitor and although the urge to zoom down the stock market can thus be considered : given specific evidence of intent can betake action verdict.

the rules are anti-competitive action verdict. Such documents no longer need to prove again. Almost the same can be said ((confession)) in Iran as evidence in legal proceedings because it is the king. Nevertheless, the evidence suggests that it indirectly in the form of inappropriate behavior you have to prove ((intent)) firm speaks. if an enterprise is engaged in predatory pattern durable in its structure ((this is the usual behavior of business firms unfair behavior etc.)) and denied Sazanh other financial institutions or other anti-competitive behavior in general which will lead to the elimination of monopoly and competition could also find reasons to support the decision to try for a monopolist. Indeed Chnachh.... Any firm or to achieve monopoly and attempt to monopolize it can also be convicted on charges of trying monopoly ((Strickland, 2009, p40. Brayym if imitation as can be this anti-competitive firms like ((mass start)) compared to that in criminal law in both aforementioned result is not achieved. 's a good way to meditate on the concept of behavior that can be difficultis recorded the carpet trade is good for removing the appearance of competitors in the furniture to take actions that might undermine its rivals in their careers!

against the rival that such stability in the market and not strong (cause no) other Msalyst this. a refraining from allowing a competitor who uses some basic facilities to successfully compete 4 without any occupational qualification it can be said that subject to paragraph 2 of the Sherman Act that refers to the violation of its provisions. as seen in the competition and deal with anti-competitive behavior the United States very small perfect rights realistic and detailed looks into the competitive behavior of individuals in this stage is very sensitive to it (Lea, 2000, p14)

may be manufactured merely by having a very high impact of high- quality products to the market and what is it legal ?practice may continue to expand as much as possible so spread monopoly cause harm to other competitors provide. for example, this action may cause the industry to provide products Ybkhshydn inventions or improvements that may be operated with the samebring are 2 ways : (Hosted, Feb 2011, p84) First take charge of the case is rare.provided that the total amount Barftarhay inappropriate and unjust, illegal and will result in trade restrictions. because the firm is a monopolist in its own unique competitive situation, it is desirable does not need to keep the authoritiesholds if the authorities can extend the anti- competitive actions is assumed and is punishable.We are arguing and fighting to stay in the market or depriving them of access to their customers is correct. In the past several years, lawsuits against Microsoft Corporation on the issues raised in the Court of Justice in its monopolistic claims to be discovered. One of which was the monopoly of the claims relating to the maintenance of Justice was rejected. Practice effects of the competition processes perspectivesomehow this style runs Nmaydkh harm to competition is not Hosted, June 2010, p 67)). briefly studying monopoly or good practices and unfair seemingly competitive section 2 of the Sherman Act would violate. maintain or expand even legalis not considered but may also be useful.court about the case design is very important. (Simonetti, 2011, p40) link between competitors in a competitive society, United States of America should be monitored closely by anti-competitive regulations because they simply make conspiracy Find comprehensiveness and universality and Khlvsyt that can play havoc and destroy the competition. though cartels which forms of behavior such as commodity prices or divide markets not only in itself illegal but prosecution policies it provides anti-competitive provisions. However, I detailed review of important factors should not between rival businessmen job dissatisfaction among the common people. Because it's so close monitoring Cardan argued the principle of freedom of trade in the manifestation of freedom of trade such United States of America is in contrast to. 's A kind of large share of the license link between competitors in the competitive small but significant anti-competitive rules of the association and relationship with this kind of segmentation can be inferred.be accountable under the law.communicative goals are legitimate secure a competitive field.the verdict Veroniquede, Edward, 2008, p8)). In particular, the communication between competitors to accompany the combined treatment with just unfair anti-competitive behavior of these looks.mental interactions and conduct their subjective intent. 's a consensus on this subject can be a document or an oral commitment Kitty or a mere exchange (the consistory 1387, pp. 454) or even mention the male competitors chasecompetition from other companies and competitors, it may be safe Mnayb against anti-competitive behavior especially businesses to be careful when engaging in any conduct that would justifies the behavior of the business a from becoming stagnant. to have that talk goes back to the perhaps discussion ((money laundering)) because the economic system in which topics such behavior means that a firm or company or any company engaged in the business may be 
incorrect ((money laundering)) is mainly composed of very very dangerous and deadly for country's economy and people.

The Price Determine : Some legal scholars America) pricing (competition is the beating heart of the market the agreement between competitors who are tying their own prices for their belief in the idea that their sole discretion ((actual or potential threatis for the prosecution. exact price of a certain harmony which does not require or if prices are not set by an agreement in the near future will be placed in a position that can be specified levels highly.

The agreement on the price of a conspiracy between competitors to fix prices is illegal per se or eliminate credit conditions and further determine the price based on that.Finally an agreement setting a minimum price and a maximum price, is illegal under the law in America. Despite agreement that set maximum prices competitive effects will be discussed the Supreme Court declared that the United States of America is a very sensitive issue price at which competition is allowed and not allowed to set prices to determine the maximum and minimum prices. Even in cases where the beneficial effects of competition expected !also signing the civil rights and anti-competitive provisions Brayym conditions in fact, determine prices (maximum and minimum) is at odds with Mqtzay essence of the contract. actually set prices (minimum and maximum) with Mqtzay competitive nature of the conflict.provided (Anthoney, 2010, p18).

In fact, anti-competitive regulations and policy provisions, the price is competitive. Consequently, the behavior itself provides grounds prosecution. And legally it is anti-competitive. Rivals that are agreed between themselves thatrandom effects and the same set of prices (maximum and minimum) is. courts are keen to hear evidence against anti-competition claims based on the type of anti-competitive practices that are fair and reasonable rules after hearing the defense actingalthough not directly intended to damage but the verbs which works exactly in the virtual world of competition, it acts as a set of maximum and minimum price quartiles are considered anti-competitive. enterprises to $\langle\mathrm{br}\rangle \mathrm{a}$ free market economy America numerous (Sheildcourt for the Nbvd doubts had arisen that may be inconsistent with the principle of fair treatment in the competition. Such an exchange is not generally prohibited unless they have a direct effect on prices and backed competition regulations may impact future transactions. So we conclude that the issue is so sensitive pricing that legislators in the United States changed all ways and it depends on the competition and it has imposed heavy penalties. Best Help and plummet in this way is more specific and current information exchange to take place in America trade association the risk of anti-competitive regulations threaten more defects. The criterion is the amount of information exchange can take place in America trade association the nature and mode of action the greater the risk of anti-competitive violations threatened. Because it is visible.either maximum or minimum. an interesting development in the federal business regulations regarding this topic is that section 5 of the Act ((achieving an invitation to collude on prices (minimum and maximum) in situations where therequires ((contract... 2...)) can be likened (consistory 1387, p 287). Determine the price of a traditional business electronic commerce on the traditional uses but its performance is impressive and can be used in all areas. The Telecommunications ((T)) computers and electronic commerce in the airline branch which they are defined. What are the implications for e-commerce is the topic of the competition categories the difference in the way the competition does not matter. The reason is not that the way business is different so it should not be a difference in the general principles and rules of trade.. Then you are competing with e-commerce to disturb the order of the unfair treatment... Be applied. Punishable own (Electronic Commerce Act) and if not negated would be anti-competitive regulations.prices are set the criminal penalty is waived only to legal penalties that. actually due to the nature of our ecommerce ((speed)) is an integral part of the hearing process, it automatically be swift which it is trying to ignore the possible criminal penalties. because today we act quickly especially in the context of e-commerce merchants, character comes first Mqtzay speed will find that it is activities and to the extent possible to stop it (Buttaiea, 2011, p29). For example, on a risky and risk- binding agreement between the two rivals is planned under an agreement between two competitors who entered the market they are both alone in a way that none of they are each into not. The Tvafqshan on this is the principle of the independence of the firm or financial institution has violated his freedom and other freedoms are subject to..malpractice and negligence claims against the organization that has been introduced ((Rutherford, 2010, p49. if trade restrictions and competitive prices is directly related to the work efficiency and production or business establishments in fact, jurisdiction to (proceedings) arethisMhal be done is not a remedy anti-competitive regulations, except to say that the basic principle of equality of competitors in the competitive world has violated and is looking at the issue of discrimination. example: if 4customers can destroy the credibility of the factory products that are sure to harm the plant. in the first case and assume first the factory wants to set a maximum price and in the second case the minimum price the latter is more likely (Boundin,facilities will be on hand to provide customer service that is 
associated with it such as repairs and... 0 pursuant to Section 1 of the Sherman Act however, set a minimum resale of their per se illegal. in fact the minimum price resale for prime time in 1911 illegally was considered. Yet the Supreme Federal Court America to officially rejected this PSU but denied its positive impact on competition not. 's a small gap in the law itself lead to negative effects are numerous. Federal Supreme Court which unfolds in America was when it was decided to divide ((dealer who was not satisfied with the transaction (the inner mind and intention) of the proposed prices and contract ended after the factory is one of the litigants had received a complaint regarding the same subject in accordance with the principles of anti-competitive regulations dealer is entitled ' no it 's just based on that factor alone, there was agreement that some kind of acceptable agreement whereby Sherman Act is. though the sharp -sighted view of the restrictions that are happening in the world of competition, look we discover that all of them (except in exceptional cases) based on consensus and coordination between the parties has been a loss of focus onrisks involved in a successful campaign to criticize the competition each competitor's exclusion of profit which may have serious issues are debated and disputed (Markus, 2009, p39). Indeed, it would be the Mhalcan not be helped but to say that the provisions of anticompetitive equality competitors that the essentials of the world competition a trampled to appear discriminatory to subject looks 2. example: if 4 to 5 drilling companies mine in a mountain valley, the only means of accessing all of which are involved in the ongoing risk of a harmful or dangerous the denial of achieving on the illegal reasonable company may fifth. ina exceptional seen.

The first law against competition (Sherman) in 1890 in response to the waves of the great economy then America's businesses to achieve monopoly merger were adopted. Mingle authoritative already subject to regulations against competition. Division 7 of the Act Clayton devoted to this subject Veroniquede, 2008, p22)) this section of the Act of 1914 was passed until 1950, and then until 1980 the following (mingle authoritative) strengthened so that now bansthe underlying cause (William, Dec 2008, p36) or to establish a monopoly lead is prohibited. in this part of the law, the legislator United States of America may use the word and then sometimes it is the first state law2009, p65). these sections of the Act also does not distinguish the difference between getting to mingle. whether it be through special powers whether through stock split large firms that are heavily affected by market competition iswhether the shares is solely whether any part of the assets of and deny us justice does not. exceptionally interesting and important is to be sure you firmly Vmmzvj of how legitimate the first who wants based on cooperation 1 as well as partnerships is through the open rejection does not give us Mshmv section 7 of the Clayton Act would be. 's law (Clayton) of different ways to apply it where it is about any way to mingle among competitors that possible (cross- mingle) and also between clients and preparing raw material for commercial entities (vertical merger) and in general, the company that is not the way to work. (mingle mix) ((Stottije, Daniel, 2010, p42. in fact, after we realized that it was his legislator United States of America tried all the ways that lead to mingle authoritative financial institution is closed. because of the way the first case (mixed up) or more competing mingle among themselves all of whom are committed acts which although apparently $100 \%$ legitimate but in fact it is anti-competitive because they spend doing this is anti-competitive. but the second (domination) when institutionsCourt interpretations of the federal courts' America branch. such acts (mingle) No violation of this section of the Clayton Act, do not be. actually spent performing such acts in violation of this section of law violated three provisions in the general case follows (Act Federal Trade - law Clayton - Comments branch antitrust whose legal validity has.) in a file typical trying to mingle the necessary condition that must be firms that as soon as documents, agreements were recorded 2 they are liable to prosecution. then Chnachh that we were once their contract parties should be prosecuted under the law because they spend doing their action is anticompetitive and Chnachh explained earlier legislator United States of America have tried to consider all the ways that it is anti-competitive because it Bbnddv spend doing this has a strong potential for anti-competitive actions the law is exactly the term " void " has the same rights that actually means is that the contract in question ((Livestock canceled)) as well as the legal and the virtual world and the place has no legal validity. however questions regarding ((competition)) remains in this area. institution that has recorded document of agreement What are punishable by both parties.

\section{Conclusion}

Some of the things that were briefly described. Some specific jobs such as annuities factories and warehouses.... Had suggested that a comprehensive list of practices to ensure healthy competition and unhealthy because it is prepared for the competition and for the businessmen to even inadvertently done well to anti-competitive practices.some of the top scholars of competition law gave way to describe it : first : competitors do not talk about pricing. actually do not determine prices. In fact, the way things can be said Rami most fundamental criterion leading competitive clean healthy behavior is unhealthy. Which was described in detail previously.

Second : Competitors must agree with the other competitors that remain in a particular market or not. 
therefore it shall be prevented. actually believe these fundamental Rahkarhhay legal scholars have offered competing Weber, contrary to the belief of some business establishments must provide practical avoided. third : Feel free tradetake at each stage, and with everyone (whether natural or legal) or to both causes. Whatever the nature of competition automatically bring Svaastfadh also be looking at factors such as the competitive world of chains are connected if an opponent is guilty of commercial exploitation the suffering of others are unconscious andand for its enforcement shall be determined. determine any supermarket and... The competition is open to anyone whether a natural or legal person is entitled to spend and can not be selfish andreduced competition and it is harmful. way do next : if your business has some special powers. should consider the impact of competitors' actions relating to any act or conduct of a planned order isperson the goods will be with the other person Nbndd such agreements may be permitted in very rare circumstances are very complex and many states have exceptions. but in general, such an agreement is prohibited by the law.

for the majority of society. actually the norm for public Drazhan unwritten rule that all are happy with it especially on economic issues and especially the problem of competition. compete in the new day is more like an activity that requirescustomary role as a source Tkmbly was not neglected.

In fact, in America whether natural or legal person is a lawyer or a legal advisor in the field of legal problems.... They use. But the competition is far more important and more specifically Baystaz lawyers adept and skilled in use.the competition has improved dramatically in the course of political and military objectives of competition protection. because in America the very expensive and of weapons manufacturing sites profits made in to the factory of the people holders fillpossible.that unfair behavior control have not discussed it

\section{References}

Abel, M., \& Mateus, M. (2010). Competition law \& Economic advance in competition policy in U.S.

Anthoney, J. (2010). Pricing Protecting Competition law Theory in U.S.

Boundin, M. (2009). Competition law Article in Harvard law school.

Buttaiea, E. (2011). Anti competitive law Article in U.S.

Dinn, J. (2008). Compliance Guide Antitrust law Book in U.S.

Dinn, J. (2010). Antitrust book in U.S.

Gilles, A. (2009). Anti competitive Book U.S.

Hosted, J. (Feb 2011). Antitrust Book in U.S.

Hosted, J. (June 2010). One firm worldwide Book in California U.S.

James, A. (2008). Provision Regional trade of U.S book.

Katoozian Naser 1387 of the Civil Code on existing legal order, emission levels.

Lea, wh. (2006). Article of Amendment of Anti competitive act in U.S.

Markesner, J. (2009). Describe Provision Anti competitive rules Article in U.S.

Niesle, M. (2010). Anti competitive Article of U.S.A_ New york.

Rutherford, Th. (2008). Antitrust Book in U.S.

Rutherford, Th. (2010). Anti competitive rules \& shifting Aspect in U.S.

Shield, J. (Dec 2009). Antitrust Book in U.S.

Simonetti, M. (2011). An overview of Unfair competition law Book of U.S.

Stem, M. (2009). Anti competitive Agreement Book of U.S.A.

Stottije, S., \& Daniel, R. (2010). Enforcement of Anti trust in U.S.

Teresa, M. (2007). Competition law \& Economic Advance Book in U.S.

Teresa, M. (2007). Competition law \& Economic Advance Book in U.S.

Veroniquede, S., \& Edward, H. (2008). International Competition law of U.S.

William, F., \& Shughart, N. (Dec 2008). Texas unfair competition law of united states. 


\section{Copyrights}

Copyright for this article is retained by the author(s), with first publication rights granted to the journal.

This is an open-access article distributed under the terms and conditions of the Creative Commons Attribution license (http://creativecommons.org/licenses/by/3.0/). 